\title{
Analysis of Physical Integrity Indicator on Environmental Sustainability in The Tourism Industry: Case Study in Padang Pariaman Regency
}

\author{
Nofriya $^{1 *}$, Ahmad Fadhly ${ }^{2}$ \\ ${ }^{1}$ Environmental Engineering Study Program, Sekolah Tinggi Teknologi Industri Padang \\ ${ }^{2}$ Mining Engineering Study Program, Sekolah Tinggi Teknologi Industri Padang \\ *corresponding author email: nofriyafirdaus@gmail.com
}

\begin{tabular}{llcl} 
Article history & & & \\
\hline Received & Received in revised form & Accepted & Available online \\
11 September 2020 & 11 November 2020 & 29 December 2020 & 31 December 2020 \\
\hline
\end{tabular}

\begin{abstract}
One of the development missions of Padang Pariaman Regency is to increase the potential for regional competitiveness through the development of tourism, transportation, trade, spatial planning, and environmental management. However, in the tourism policy has not seen the synergy of developing tourist destinations with environmental sustainability. This study evaluates physical integrity indicators in tourism activities in Padang Pariaman Regency to achieve environmentally sustainable development. This research uses a qualitative approach. Data were collected using in-depth interviews, document reviews, and observation of tourism objects. Data analysis was carried out by analyzing the themes and contents by triangulating the interviews' results, observing the results, and reviewing the documents. The results showed no special permit regarding environmental sustainability for tourism activities. However, each tourist attraction had its policy to protect the surrounding environment. The community is empowered to manage tourist objects and have local wisdom as a code of ethics in safeguarding the tourist area. The regional landscape is still preserved, but the beach's tourist objects are vulnerable to abrasion disturbances. It is recommended that the government make a policy to defend the physical integrity of the tourist attraction sites so that the concept of environmental sustainability can be achieved.
\end{abstract}

Key words: Environmentally sustainable development, Physical integrity, Pro-environmental tourism

Abstrak: Salah satu misi pembangunan Kabupaten Padang Pariaman adalah meningkatkan potensi daya saing daerah melalui pengembangan pariwisata, transportasi, perdagangan, penataan ruang, dan pengelolaan lingkungan. Namun dalam kebijakan pariwisata belum terlihat sinergi pengembangan destinasi wisata dengan kelestarian lingkungan. Studi ini mengevaluasi indikator integritas fisik dalam kegiatan pariwisata di Kabupaten Padang Pariaman untuk mewujudkan pembangunan yang berwawasan lingkungan. Penelitian ini menggunakan pendekatan kualitatif. Pengumpulan data dilakukan dengan wawancara mendalam, telaah dokumen, dan observasi objek wisata. Analisis data dilakukan dengan menganalisis tema dan isi dengan melakukan triangulasi hasil wawancara, observasi hasil, dan telaah dokumen. Hasil penelitian menunjukkan tidak adanya izin khusus terkait kelestarian lingkungan untuk kegiatan pariwisata. Namun, setiap objek wisata memiliki kebijakan untuk menjaga lingkungan sekitarnya. Masyarakat diberdayakan untuk mengelola objek wisata dan memiliki kearifan lokal sebagai kode etik dalam menjaga kawasan wisata. Bentang alam kawasan ini masih terjaga kelestariannya, namun obyek wisata pantai ini rentan terhadap gangguan abrasi. Disarankan agar pemerintah mengambil kebijakan untuk menjaga keutuhan fisik lokasi objek wisata agar konsep kelestarian lingkungan dapat tercapai.

Katakunci : Pembangunan berkelanjutan secara lingkungan, Integritas fisik, Pariwisata pro lingkungan

\section{Introduction}

Tourism growth is one of twelve socioeconomic trends that have been included in "The Great Acceleration" or "Great Acceleration" in human activity since 1950 . This activity coincides with dramatic increases in population, urbanization, income, transportation, and telecommunications. Furthermore, this affects substantial changes in Earth's ecosystem's structure and function [1]. Rapid advances in transportation and communication increase the desire and ability of humans to travel.
International tourist arrivals are projected to double between 2010 and 2030, with arrivals in developing countries growing at twice than developed countries [2].

This condition has an impact on the environment. They are direct effects (such as changes in weather patterns and sea-level rise) and indirect effects (such as the distribution of biodiversity and water availability) [3]. So to overcome this, a sustainable tourism policy is needed. The concept of tourism associated with sustainability is a tourism 
activity that considers environmental, economic, and socio-cultural components [4].

In Indonesia, regulation of tourism policy stated in the Ministry of Tourism Regulation Number 14 of 2016 concerning Guidelines for Sustainable Tourism Destinations. This regulation considers environmental criteria for carrying out tourism activities [5]. Besides, according to Law Number 10 of 2009 concerning Tourism, it is stated that the implementation of tourism must be carried out with the principle of preserving nature and the environment [6].

In West Sumatra Provincial Regulation Number 3 of 2014 about the Tourism Development Master Plan for West Sumatra Province 2014-2025, it is stated that tourism development activities are based on environmental preservation and realizing a green economy (environmentally friendly) in every tourism business activity. In addition, this regulation states that policy are needed to maintain the carrying capacity of the environment[7].

Tourism activities in Padang Pariaman Regency are growing very fast. In 2018, the government was targeting 60,000 domestic and foreign tourist arrivals. However, tourist visits' realization exceeded expectations by 183,600 people or $306 \%$ of the set target. This proves that tourism activity is a leading activity in Padang Pariaman Regency, positively impacting the environment. From the results of tracing local, regional policies, there is no specific pro-environment policy to support sustainable development, but more on tourism management and development from an economic perspective. One of the development missions of Padang Pariaman Regency is to increase the potential for regional competitiveness through the development of tourism, transportation, trade, spatial planning, and environmental management. However, the tourism policy has not seen the synergy of developing tourist destinations with environmental sustainability [8].

One of the indicators considered in the tourism policy to fit the concept of environmentally sustainable development is physical integrity. This indicator is an activity to maintain and improve the landscape's quality and avoid decreasing the tourism area's visual rate. It is an essential factor for the sustainability of tourism and relates to the local community's social aspects. Policies that need to be

\section{Results and Discussion}

\subsection{Tourism development policies to protect the local environment}

From the results of the interview, it was found that there was no special environmental permit for tourism activities, but only the clusters that have been defined for tourism activities.

"This has been regulated by the regional regulation considered include ensuring tourism development follows local environmental conditions, minimizing the physical impact of tourism activities, and maintaining regional landscapes [9]. Therefore, this study aims to evaluate physical integrity indicators in tourism activities in Padang Pariaman Regency to achieve environmentally sustainable development.

\section{Material and Methods}

This study uses a qualitative approach, which is used to understand the phenomenon of a thing deeply and holistically to reveal how reality works. To get this truth, researchers find out directly about the object under study, and the item provides direct answers to the researcher. This research is categorized as a phenomenological study where indepth interviews are the primary data source. Research informants are determined by their ability to answer the questions. Data also collected using a review of documents related to research, field notes, photos, videos, and recordings.

Data was collected through in-depth interviews with informants who were considered to know the ins and outs of research to answer questions according to the research objectives. The informants are from the Tourism Office (Informan 1 and 2), the Environmental Office (Informant 3 and 4), the manager of the tourist attraction, which is the most popular tourist attraction (Anai Land - Informant 5, Nyarai waterfall - Informant 6, Tiram Beach Informant 7, and Syekh Burhanuddin religious tourism - Informant 8), and hotel managers (Informant 9). The data collection tools used were interview guides, interview note forms, and voice recorder. Also, observations were made regarding environmental conditions in several tourist objects in Padang Pariaman Regency.

The data was processed by copying the results of the interview in the interview transcript. Data are reduced according to the theme using a matrix so that the data obtained is more organized. Triangulations were conducted with the results of observations and document reviews to ensure data validation. The research analysis was carried out by using content analysis techniques. It classified the research data according to the similarity of characteristics and compared to the theory

No. $9 / 2018$ on the master plan for tourism development. In Padang Pariaman Regency, it is for tourism development, and there are clusters already. " (Inf-1)

However, some tourism activities have waste management policies, minimizing footpaths to reach 
tourism objects, tree planting, mangroves, and green open spaces.

"In general, there are no environmental permits in tourist areas, but there are regulations on waste management." (Inf-4)

"Our location is in a forest area where the forest was formerly a protected forest, but now it has become a village forest or village forest after we took care of the permit. We still maintain the naturalness and maintain the existing structure without changing it, but we only use that little area as a path. " (Inf-5)

"Yes, here, done in the form of tree planting." (Inf-9)

"In spatial terms, we also pay attention to, for example, coastal tourism. Along the coast, tourism can be developed that supports the existing ecosystem there, especially mangroves. Then also there are green open spaces. " (Inf-3)

From observations to tourist objects, it is evident that there have been many activities that lead to environmental awareness. The environment becomes more beautiful with the planting of green plants and trees. There are even mangrove ecotourism activities so that visitors can be more sensitive to environmental protection issues.

The government has also budgeted an allocation of funds to repair tourist sites damaged by the earthquake conditions. In addition, the development of tourism activities reduces illegal logging activities by turning local communities into tourism actors. In the future, there are plans to develop tourism from the heritage of the Dutch era.

"Because it was damaged during the earthquake in 2009, we got renovation assistance from the APBN. With a total budget of approximately 125 billion, which is planned to be distributed gradually." (Inf-8)

"We maintain the existing conditions, and we plan to use 'Rumah Putiah', a building from the Dutch era. There will be a coffee factory, a coffee garden, and a public bath." (Inf-2)

However, there are still tourist objects that have not paid attention to environmental issues, and some are planning to do so.

\subsection{Programs to minimize the physical impact of tourism activities}

In reducing the physical impact of tourism activities, there are tourist objects that provide guides to mitigate environmental damage.

"Some tourism activities provide guides so that visitors do not damage the environment. For a route on a tourist attraction that passes a particular road, every 2-3 years, the route will
"We haven't focused on that yet." (Inf-6)

"From an environmental perspective, there is not much waste at this time. But in the long term, where will the waste be disposed of / its management becomes our homework." (Inf-7)

This can be seen from the garbage scattered around tourist objects and has not been appropriately managed. The existence of an appeal to protect the environment has not changed visitors' behavior to protect the environment properly.

The $12^{\text {th }}$ Sustainable Development Goals (SDGs) state the need for cooperation in various sectors to create green tourism [10]. Comprehensive policies are needed to ensure environmental sustainability in tourism activity [9]. Besides, the Ministry of Tourism policy in Indonesia states that is considering the implementation of tourism is to use the principle of preserving nature and the environment [6]. This clarifies by the Regulation of the Minister of Tourism Number 14 of 2016 concerning Guidelines for Sustainable Tourism Destinations that environmental impacts need to be minimized from tourism activities [5].

In ensuring tourism activities can protect the local environment, local policymakers need to design a sustainable tourism policy framework while still paying attention to a sustainable environment. Coordination between the public and private sectors can also promote a sustainable tourism industry[11].

At present, perceptions and institutional flexibility regarding tourism impacts on environmental change still need to be improved [12]. It is necessary to increase stakeholder insights and feedback mechanisms to produce effective intervention policies to promote sustainability and harmony between tourism and environmental activities.

A systemic approach involving all parties related to tourism and environmental activities is an effective way to formulate tourism policies that can simultaneously protect the environment. This requires a commitment to stakeholder engagement regarding problem formulation, problem analysis, and implementation of solution strategies [13].

change to reduce environmental impact. Also, there are instructions not to litter in several tourism activities. " (Inf-2)

"A kind of notification or billboard, maybe there are banners in every location to invite visitors not to litter. Then this is a green location all over the place, and so this river is our river that we maintain." (Inf-1) 
Public awareness managing tourist objects has started to lead to environmental sustainability. This can be seen from the arrangement of the use of the path to the tourist attraction, and the cleanliness of the river that is maintained

The government has built special locations for trade activities and restaurants around tourist sites to keep adjusting to environmental conditions.

"Like in 2019, booths have been built to accommodate traders along the road of Syekh Burhanuddin." (Inf-8)

Besides, the management of tourist objects also collaborates with the village government. They have a program for each tour group to plant tree seedlings.

"Tourists participate in reforestation, so every group that goes up to Nyarai, we must instead oblige to plant one tree seedling that we provide at the Nyarai post. The guide also controls the habit of taking out the garbage. "(Inf-5)

At this tourist location, it is seen that the waste generated is brought back to the guard post to ensure that there is no garbage dumped at tourist sites. Waste bins are provided to manage waste, and there are plans to implement the triple R (reduce-reuserecycle) program.

"In the tourism area, there is a garbage dump. The team that comes to the tourism place aims to make garbage and waste well managed." (Inf3)

"We have collaborated with tourism managers regarding waste management and triple $R$, but some tourism objects manage their waste independently." (Inf-4)

From the results of observations made by tourist objects in Padang Pariaman, there have been good waste management activities. However, in several other tourist objects, the trash that has not managed appropriately.

"We have tried before, but it's not optimal." (Inf6)

"We haven't just had a special policy, the rules for visitors have been made with banners not to litter, but it doesn't last long." (Inf-7)

In several tourist objects, there are separate trash bins between organic and organic waste. However, there is still mixed trash, so that the use of this trash can is not yet effective.

Also, the environmental code of ethics in tourism activities is carried out following the area's local wisdom. Like the concept of prohibited water/fish called 'aia/ikan larangan'. This introduces tourists to the need to protect aquatic ecosystems.
Tourism activities in this area have also paid attention to customs and respected local residents' worship activities.

"The code of ethics means our Tourism, especially we, Padang Pariaman, West Sumatra, is thick with customs, meaning that it is our place, maybe tourism should not do things that are not desirable." (Inf-1)

"We have a code of ethics; we have the concept of prohibited water. Foreigners like to fishing there. It's just special for catching back and forth again. Besides, some foreigners want to swim in bikinis, but our code of ethics is no bikinis. They have to wear the usual clothes because our ethics are at Minang. Besides that, on Friday, there are no activities at the Nyarai tourist attraction because we want to pray on Friday. " (Inf-2)

Cultivating understanding in protecting the environment is instilled from an early age at school age.

"The code of ethics is instilled from an early age in elementary to high school children in the form of adiwiyata. Our high school comes there to increase capacity, how we are good visitors and good managers. " (Inf-3)

There are Waste Bank programs, Kalpataru, and the Climate Village programs to introduce the need to minimize the physical impact of the environment.

"To increase public understanding of environmental ethics, we have a waste bank program, Kalpataru, and a climate village program." (Inf-4)

"We have a kind of announcement board, from start to finish, it's like a warning board in the contemporary language. We also have a prohibited advertisement, we sell fishing packages to tourists, but the fish are returned." (Inf-5)

From the existing tourism activities in Padang Pariaman Regency, Nyarai tourism activities with an ecotourism concept can be used as a pilot tourist object in tourism development that supports environmentally sound development. Apart from being nature-based tourism, the tourism industry at this location can empower the community to protect nature by always maintaining local wisdom, which also acts as a code of ethics for tourists and tourism managers to protect the environment.

The increase in tourists' number significantly affects tourist areas' physical impact, especially the increasing potential for damage to natural resources 
around tourist destinations. From the results of observations made, waste management at tourist sites is one of the main priorities that need to be improved because it greatly impacts the physical condition of tourist destinations. This is also found in tourist locations in other areas that find that an increase in tourists' number is followed by the rise in the amount of waste, especially during the tourist season [14].

\subsection{Territorial Landscape Maintain}

The existence of tourism activities opened in community forests has a positive impact. It reduced illegal logging activities of protected forests because there are better economic activities.

"Tourism in our area is scattered, so there is no tourism concentration, there is a sea, mountains, and waterfalls. Not much 'mass tourism' but more of particular interest. There used to be more than 150 people who worked as loggers; now they have become tour guides. " (Inf-2)

The tourism activities carried out do not change the landscape. From the observation, it can be seen that the natural conditions are still maintained, and there are no new buildings that have damaged the original landscape. The resort area is built in a particular area while even considering the beauty of the environment.

"We still maintain the landscape like some restoration. " (Inf-1)

"We build it on a small scale, just make it like a hut, so it doesn't damage." (Inf-9)

"We do not have new buildings, if we maintain existing ones, we have already restored some of them." (Inf-6)

The construction carried out has the permission of the government and local community leaders.

"Tourism activities in Padang Pariaman have not changed the landscape. If you want to change, you must have a permit first." (Inf-4)

"There has been an MoU from the local government of Padang Pariaman with residents. And the forest area already has regulations at the ministerial level. At the village level there are no binding rules yet." (Inf-5)

"There are several buildings that are being made now that do not change the landscape. There are reports of physical structures such as bridges to 'ninik mamak', the local government, and the
Following the waste hierarchy concept and Law number 18 of 2008, the paradigm of waste management must start from reducing waste (reduce, reuse, and recycle) [15], [16]. The government can make policies regarding waste reduction in the tourism industry by collaborating with the waste bank program that is already owned by the Padang Pariaman Regency government.

\section{land owners' consent. " (Inf-7)}

The condition of the Padang Pariaman Regency area, with tourist locations scattered in almost all districts, minimizes visitors' density in one place. In contrast to sites that have a location that is used as a tourist center, there will be potential changes in the landscape to facilitate tourist access in various aspects such as shopping tours, culinary tours, and lodging development. However, it is necessary to pay attention to the condition of the coastal tourism area landscape because the west coast of Padang Pariaman has a high abrasion rate of around 2.76 meters per year [17].

For this reason, a mitigation strategy is needed for this condition, planting mangroves and making wave breakers. Meanwhile, the adaptation strategy that tourism actors need to implement is landfilling as an effort to elevate tourist sites so that they are not affected by tidal flooding. Besides, floors in supporting facilities around beach attractions such as restaurants, prayer rooms need to be elevated so that seawater is not easily intruded [18]

\section{Conclusion}

The implementation of tourism activities in the District of Padang Pariaman has led to environmentally sound development. However, there has not been any collaboration between the Environment Agency, the Tourism Office, and the executors of tourism activities (managers of tourist objects, hotels, and restaurants) to formulate tourism policies. This is also followed by the discovery of environmental problems in tourism objects, especially inadequate waste management.

The condition of tourism, which is dispersed in various locations, does not affect the landscape changes. Still, it is necessary to pay attention to tourism activities on the coast that can damage high abrasion rates.

\section{Acknowledgement}

We are grateful to the Indonesian Ministry of Research and Technology / National Agency for Research and Innovation for funding this research 
through 'Penelitian Dosen Pemula' scheme in the year 2020 .

\section{References}

[1] W. Steffen, W. Broadgate, L. Deutsch, O. Gaffney, and C. Ludwig, "The trajectory of the Anthropocene: the great acceleration," Anthr. Rev., vol. 2, no. 1, pp. 81-98, 2015.

[2] UNWTO, UNWTO Tourism Highlights, vol. 2. 2014.

[3] D. Scott, S. Gössling, and C. M. Hall, "International tourism and climate change," Wiley Interdiscip. Rev. Clim. Chang., vol. 3, no. 3, pp. 213-232, 2012.

[4] W. Wu, X. Zhang, Z. Yang, W. Qin, F. Wang, and C. Wang, "Ecotourism Suitability and Zoning from the Tourist Perspective: a Nature Reserve Case Study.," Polish J. Environ. Stud., vol. 24, no. 6, 2015.

[5] Kemenpar, Peraturan Menteri Pariwisata Republik Indonesia Nomor 14 Tahun 2016 Tentang Pedoman Destinasi Pariwisata Berkelanjutan. 2016.

[6] Kemenpar, Undang-undang Republik Indonesia Nomor 10 tahun 2009 tentang Kepariwisataan. 2009, pp. 1-40.

[7] Pemerintah Provinsi Sumatera Barat, Peraturan Daerah Provinsi Sumatera Barat Nomor 3 Tahun 2014 tentang Rencana Induk Pembangunan Kepariwisataan Provinsi Sumatera Barat tahun 2014-2025. 2014.

[8] Pemkab Padang Pariaman, Laporan Kinerja Instansi Pemerintah (LAKIP) tahun 2018. Parit Malintang: Pemerintah Kabupaten Padang Pariaman, 2018.

[9] UNEP and WTO, Making Tourism More Sustainable, A Guide for Policy Maker. United Nations Environment Programme and World Tourism Organization, 2008.

[10] BPS, Potret Awal Tujuan Pembangunan Berkelanjutan (Sustainable Development Goals) di Indonesia. Jakarta: Badan Pusat Statistik, 2016.

[11] J. C. C. Lopez and K. Bhaktikul, "Sustainable environment and tourism industry: An institutional policy analysis of Northeastern Thailand," Polish J. Environ. Stud., vol. 27, no. 1, pp. 31-37, 2018.

[12] B. Amelung and A. Moreno, "Costing the impact of climate change on tourism in Europe: results of the PESETA project," Clim. Change, vol. 112, no. 1, pp. 83-100, 2012.

[13] B. Amelung et al., "The value of agent-based modelling for assessing tourism-environment interactions in the Anthropocene," Curr. Opin. Environ. Sustain., vol. 23, pp. 46-53, 2016.
[14] Nofriya, A. Arbain, and S. Lenggogeni, "Dampak Lingkungan Akibat Kegiatan Pariwisata di Kota Bukittinggi," J. Dampak, vol. 16, no. 2, pp. 86-94, 2019.

[15] M. Gharfalkar, R. Court, C. Campbell, Z. Ali, and G. Hillier, "Analysis of waste hierarchy in the European waste directive 2008/98/EC," Waste Manag., vol. 39, pp. 305-313, 2015.

[16] Sekretariat Negara RI, Undang-Undang Nomor 18 tahun 2008 tentang Pengelolaan Sampah. 2008.

[17] L. Syaharani and T. Triyatno, "Analisis Perubahan Garis Pantai Kabupaten Padang Pariaman dan Kota Pariaman Tahun 19882018 Menggunakan Digital Shoreline Analysis System (DSAS)," J. Buana, vol. 3, no. 5, pp. 1056-1067, 2019.

[18] M. K. Abda, "Mitigasi Bencana terhadap Abrasi Pantai di Kuala Leugekecamatan Aceh Timur," J. Samudra Geogr., vol. 2, no. 1, pp. $1-4,2019$. 